\title{
Root perforations treatment using mineral trioxide aggregate and Portland cements ${ }^{1}$
}

\author{
Cimentos de agregado trióxido mineral e Portland no tratamento de perfurações radiculares
}

\author{
José Dias da Silva Neto', Rafael Horácio de Brito"II, Taylor Brandão SchnaiderII, Alfredo Gragnani ${ }^{\mathrm{IV}}$, Mírian Engelmanv ${ }^{\mathrm{II}}$ Lydia \\ Masako Ferreira ${ }^{\mathrm{VI}}$
}

\author{
I'Fellow PhD Degree, Postgraduate Program in Plastic Surgery, UNIFESP, SP, Brazil.

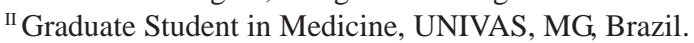

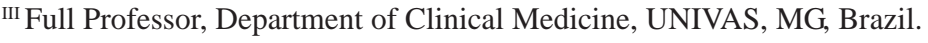 \\ ${ }^{\text {Iv }}$ Associate Professor, Department of Surgery, UNIFESP, SP, Brazil. \\ ${ }^{\vee}$ Associate Professor, Department of Clinical Medicine, UNIVAS, MG, Brazil. \\ ${ }^{\mathrm{VI}}$ Chairwoman, Full Professor, Division of Plastic Surgery, Head of the Department of Surgery, UNIFESP, SP, Brazil.
}

\begin{abstract}
Purpose: Clinical, radiological and histological evaluation of root perforations treated with mineral trioxide aggregate (MTA) or Portland cements, and calcium sulfate barrier. Methods: One molar and 11 premolar teeth of a male mongrel dog received endodontic treatment and furcations were perforated with a high-speed round bur and treated with a calcium sulfate barrier. MTA, Portland cement type II (PCII) and type V (PCV), and white Portland cement (WPC) were used as obturation materials. The teeth were restored with composite resin and periapical radiographs were taken. The animal was euthanized 120 days post-surgery for treatment evaluation. Results: Right lower first premolar (MTA), right lower third premolar (PCV), left lower second premolar (MTA), and right lower second premolar (WPC): clinically normal, slightly radio-transparent area on the furcation, little inflammatory infiltrate, and new-bone formation. Left lower third premolar (PCII), right upper first premolar (WPC), right upper third premolar (PCII), and left upper first molar (PCV): clinically normal, radiopaque area on the furcation, and new-bone formation. Right upper second premolar (MTA), left upper second premolar (WPC), left upper third premolar (PCII): presence of furcation lesion, large radiolucent area, and intense inflammatory infiltrate. Conclusion: All obturation materials used in this study induced new-bone formation.
\end{abstract}

Key words: Dental Cements. Furcation Defects. Biocompatible Materials. Calcium Sulfate. Dogs.

\section{RESUMO}

Objetivo: Avaliar clínica, radiológica e histologicamente perfurações radiculares tratadas com MTA e cimentos Portland, com barreira de sulfato de cálcio. Métodos: A amostra foi constituída por 11 dentes pré-molares e um molar de cão macho, sem raça definida. Após tratamento endodôntico realizaram-se perfurações nas furcas com broca esférica de alta rotação e barreira de sulfato de cálcio. Foram utiliados os cimentos MTA, Portland tipo II (CPII), Portland tipo V (CPV) e Portland branco estrutural (CPB). Os dentes foram restaurados com resina composta e submetidos a radiografias periapicais. O animal foi confinado por 120 dias e submetido à eutanásia para avaliações. Resultados: Primeiro pré-molar inferior direito (MTA), terceiro pré-molar inferior direito (CPV), segundo pré-molar inferior esquerdo (MTA) e segundo pré-molar inferior direito (CPB): clinicamente normal; leve área radiotransparente na furca; pequeno infiltrado inflamatório e neoformação óssea. Terceiro pré-molar inferior esquerdo (CPII), primeiro pré-molar superior direito (CPB), terceiro pré-molar superior direito (CPII) e primeiro molar superior esquerdo (CPV): clinicamente normal; área radiopaca na furca; neoformação óssea. Segundo pré-molar superior direito (MTA), segundo pré-molar superior esquerdo (CPB) e terceiro pré-molar superior esquerdo (CPII): clinicamente com lesão na furca; intensa área radiolucida; infiltrado inflamatório intenso. Conclusão: Todos os cimentos induziram a neoformação óssea.

Descritores: Cimentos Dentários. Defeitos da Furca. Materiais Biocompatíveis. Sulfato de Cálcio. Cães.

${ }^{1}$ Research performed at the Postgraduate Program in Plastic Surgery, Federal University of Sao Paulo (UNIFESP) and Vale do Sapucai University (UNIVAS), Brazil.

\section{Introduction}

Endodontics is a microsurgical specialty in dental microsurgery prone to complications that may affect prognosis. Root perforation is defined as an artificial opening of iatrogenic etiology, which may also be caused by pathological conditions, caries process or resorption, and results in the communication of the pulp cavity with periodontal tissues and alveolar bone ${ }^{1}$. The periradicular tissues adjacent to the endodontic perforations contain a larger variety of immunocompetent cells which play an 
important role in pathogenesis of inflammation and repair mechanisms ${ }^{2}$. The pulp chamber floor is the part of the tooth where most of the perforations occur ${ }^{3}$.

The cements used in the treatment of root perforations remain in close contact with periradicular tissues. The essential requirement for repair of root perforations is the use of cements with physical, chemical and biological properties that neither adversely affect cells involved in the repair process nor act as a foreign body ${ }^{4}$. An important problem associated with the use of some cements is the difficulty to limit the amount of cement placed in the perforation canal. The lack of a barrier or stop at the moment of condensation of the cement results in extrusion of obturation material into the periodontal space. In order to remediate this problem, some authors have indicated the use of an internal matrix that acts as a barrier, preventing extrusion of cement ${ }^{5}$. Calcium sulfate has been used in the treatment of furcation perforations to prevent extrusion of obturation material and facilitate the repair process $^{5}$.

Mineral trioxide aggregate (MTA), developed by Mahound Torabinejad in the early 1990s, is composed of tricalcium silicate, dicalcium silicate, tricalcium aluminate, tetracalcium aluminoferrate, bismuth oxide (radiopaque agent) and hydrated calcium sulfate (gypsum). MTA is the most indicated obturation material because of its excellent physical and chemical properties and biocompatibility. It has been successfully used in endodontic surgery, direct pulp capping, apexification, root resorption, and repair of lateral root perforations and molar furcation perforations ${ }^{6}$.

Portland cement, the most common type of cement in use around the world, was invented and patented by Koseph Aspdin in 1824 in England. The main components of Portland cement are tricalcium silicate, dicalcium silicate, tricalcium aluminate, tetracalcium aluminoferrate, and hydrated calcium sulfate ${ }^{7}$. The composition of Portland cement is very similar to that of $\mathrm{MTA}^{8}$. Other similarities between these two materials include $\mathrm{pH}^{9}$, density $^{10}$, antimicrobial activity, biocompatibility ${ }^{11}$ and lower resistance to compression ${ }^{12}$.

Ordinary (type I) and white Portland cements have been compared with MTA in recent experimental studies on pulp capping in dogs ${ }^{13}$ rat submucosal connective tissue ${ }^{14}$ repair of root perforation of dog premolar teeth ${ }^{15}$ and rat subcutaneous connective tissue ${ }^{16}$. Results obtained in these studies support the idea that both ordinary and white Portland cements have the potential to be used in clinical applications similar to those of MTA because of their physical, chemical and biological properties. However, due to the addition of bismuth oxide, MTA is less resistant to compressions and more porous than Portland cements ${ }^{17}$.

The characteristics of Portland cements show that type I cements, known as ordinary or general purpose cements, exhibit poor physical properties. On the other hand, additives are added to the composition of type II, type V, and decorative cements, such as white Portland cement, resulting in cements with excellent physical properties, such as high resistance to compression ${ }^{17}$. Therefore, new experimental studies on Portland cements with additives are necessary to identify their biological properties, and to investigate their use as a root-filling material combined with calcium sulfate as a barrier, considering the forces exerted on tooth roots during mastication.
The clinical use of Portland cement would be welcome by the public health sector because of its ease of acquisition and lower cost compared with MTA. Therefore, we consider relevant to perform histological studies of tissue regeneration in root perforations treated with a combination of barrier material and either white Portland cement or type II or type V slag Portland cement.

\section{Methods}

The study was approved by the Research Ethics Committee of the Federal University of Sao Paulo (UNIFESP) and Vale do Sapucai University (UNIVAS). The animal received humane care in strict compliance with the Council for International Organization of Medical Sciences (CIOMS) ethical code for animal experimentation (WHO Chronicle 1985; 39(2):51-6 and the principles of the Brazilian College on Animal Experimentation).

This was a randomized, primary, experimental, analytical, prospective longitudinal study. The sample consisted of 1 upper molar, 5 upper premolar and 6 lower premolar teeth of a mongrel dog weighing between 10 and $15 \mathrm{~kg}$, and aged between 1 and 1.5 years. The dog was selected at the dog pound of the Zoonosis Control Center of Pouso Alegre-MG and transferred to the confinement area in a veterinary clinic one week prior to the beginning of the study. A qualified veterinarian cared for the dog before and after the surgical procedure. The dog was kept in an individual kennel (cleaned daily), and received commercial dog food and water ad libitum. The animal was vaccinated and given medication during the pre- and postoperative periods.

The surgical procedures were carried out in the Laboratory of Surgical Techniques of the Vale do Sapucai University (UNIVAS), Pouso Alegre-MG. Acepromazine and xylazine (2 mg/kg) were administered intramuscularly into the glutal region as preanesthetic medication. The dog was anesthetized intravenously with sodium thiopental $(12.5 \mathrm{mg} / \mathrm{kg})$. The animal was intubated with a high-compliance, low-pressure cuffed endotracheal tube (no. 38). During the surgery, a $0.9 \%$ isotonic sodium chloride solution was administered intravenously to the dog. Regional infiltration anesthesia ( 0.25 to $1 \mathrm{ml}$ of $1 \%$ lidocaine) was administered to periapical region of the involved teeth.

One periapical radiograph was taken from each dental quadrant. A dental x-ray film holder was used to allow the film to be placed parallel to the teeth to ensure that proportions were maintained on the image. Radiographs were taken using x-ray equipment (Dabi Atlante, Ribeirão Preto, Brazil). The dimensions of the film were $5.5 \mathrm{~cm} \times 7 \mathrm{~cm}$, and exposure time per radiograph was $1 \mathrm{~s}$.

The tooth crowns were mechanically cleaned using an ultrasound device (Dabi Atlante, Brazil). The teeth in each quadrant were isolated using a Backhaus towel clamp, Gosset retractor, rubber dam and clamps 206 attached to the superior and inferior first molar teeth. The surgical site was aseptically prepared with $70 \%$ ethanol and $0.3 \%$ iodine, and neutralized with 1:1 ethanol-ether solution. The coronal opening was made with a diamond round bur (1016 HL) in a water-cooled high speed handpiece at $3600 \mathrm{rpm}$. 
The endodontic instrumentation and obturation techniques used in this study were described by Moore et al. ${ }^{18}$. The canals were located using a canal probe, and the crown-down instrumentation was started. The canals were divided into three thirds: the cervical, middle and apical thirds. K-type files of the first (sizes 15 to 40 ) and second (sizes 45 to 80 ) series were used in the procedure. K-files \#50, \#45, \#40, and \#35 were used in the cervical third, and K-files \#30, \#25, and \#20 were used in the middle third. In the apical third, the working length was determined and foramen patency was established using the K-files \#20 and \#15 of the first series, and K-files \#10 and \#8 of the special series.

In the second phase of the instrumentation, Gates Glidden drills (Dentsply Maillefer) \#2 through \#5 were used at low-speed; step-back technique was performed with drills \#3 to \#5. The final phase of the instrumentation was carried out with rotary nickel-titanium (Ni-Ti) files (Easy Endo Slim) at controlled speed (350 rpm) and torque (2 Nm).

Throughout the procedure, the canals were irrigated and aspirated with a $2.5 \%$ sodium hypochlorite solution after each change of instrument, and with ethylenediaminetetraacetic acid (EDTA), a chelating agent, at the end of the instrumentation. The apical foramen was dried with \#25 absorbent paper points and shaped with medium gutta-percha cones (Dentsply). After, the canals were obturated with medium gutta-percha cones and AH-Plus sealer (Dentsply). Vertical condensation was done with Schilder pluggers \#1 through \#5, and furcations were perforated with a 1016 HL bur in a water-cooled high speed handpiece. Each perforation had the shape of the head of the bur. The perforation traversed the dentin and cementum (root structures), as well as the periodontium and the alveolar bone. A cursor on the body of the handpiece and the tips of the cusps of each tooth were used as reference points for the perforations. In all cases, the bone portion of the canal was filled with calcium sulfate, which was inserted with an amalgam carrier and packed with a \#4 Schilder plugger.

The 12 teeth were divided into groups according to the obturation material used, in such way that each type of obturation material was used in teeth located in different dental quadrants. The groups were as follows: (1) control group (right lower first premolar, left lower second premolar, and right upper second premolar) - treated with MTA; (2) PCII group (left lower third premolar, right upper third premolar, and left upper second premolar - treated with type II Portland cement with additive; (3) PCV (right lower third premolar, left lower first premolar, and left upper first molar) - treated with type V Portland cement with additive; and (4) WPC group (right lower second premolar, right upper first premolar, and left upper second premolar) - treated with white Portland cement.

The teeth were restored with composite resin (Carisma), and a light-curing unit (Raddi-call) was used to photopolymerize the resin. Four periapical radiographs (one of each quadrant) were taken. Analgesics and non-steroidal anti-inflammatories [acetil salicylic acid (10-25 mg/kg) and ibuprofen (10-20 mg/kg] were administered postoperatively every $12 \mathrm{~h}^{19}$.

The dog was killed by anesthetic overdose 120 days after the surgical procedure. Four periapical radiographs were taken using a dental x-ray film holder. The dental quadrants were cut and removed from the dog with a circular saw attached to an electric drill. The specimens were cut so that the treated teeth were distributed in four parts: left and right upper quadrants, and left and right lower quadrants. The four specimens were identified and placed in individual plastic containers with lids containing a decalcifying solution (558 $\mathrm{ml}$ of $10 \%$ formaldehyde and $42 \mathrm{ml}$ of $65 \%$ nitric acid). The time required for demineralization was 15 days; radiographs were taken to confirm it. After, the specimens were washed in running water for $24 \mathrm{~h}$ and embedded in paraffin. The size of the specimens was further reduced to facilitate sectioning with a microtome; 6 - $\mu$ m serial sections were cut, stained with hematoxylin-eosin and Mallory's trichrome stain, and examined with a photomicroscope (Olympus BX50, Tokyo, Japan).

New-bone formation and inflammatory infiltrate were quantitatively evaluated in each histological section. A descriptive statistical analysis was performed because the sample consisted of 12 teeth from only one animal.

\section{Results}

Findings for the teeth obturated with different cements were as follows.

The right lower first premolar (MTA), right lower third premolar (PCV), left lower second premolar (MTA), and right lower second premolar (WPC) were clinically normal, showing a slightly radio-transparent area on the furcation, little inflammatory infiltrate and new-bone formation (Figures 1 and 2).

The left lower third premolar (PCII), right upper first premolar (WPC), right upper third premolar (PCII), and left upper first molar (PCV) were clinically normal, showing a radiopaque area on the furcation, and new-bone formation (Figures 3 and 4).

The right upper second premolar (MTA), left upper second premolar (WPC), left upper third premolar (PCII) displayed a lesion in the root furcation with a large radiolucent area and intense inflammatory infiltrate.

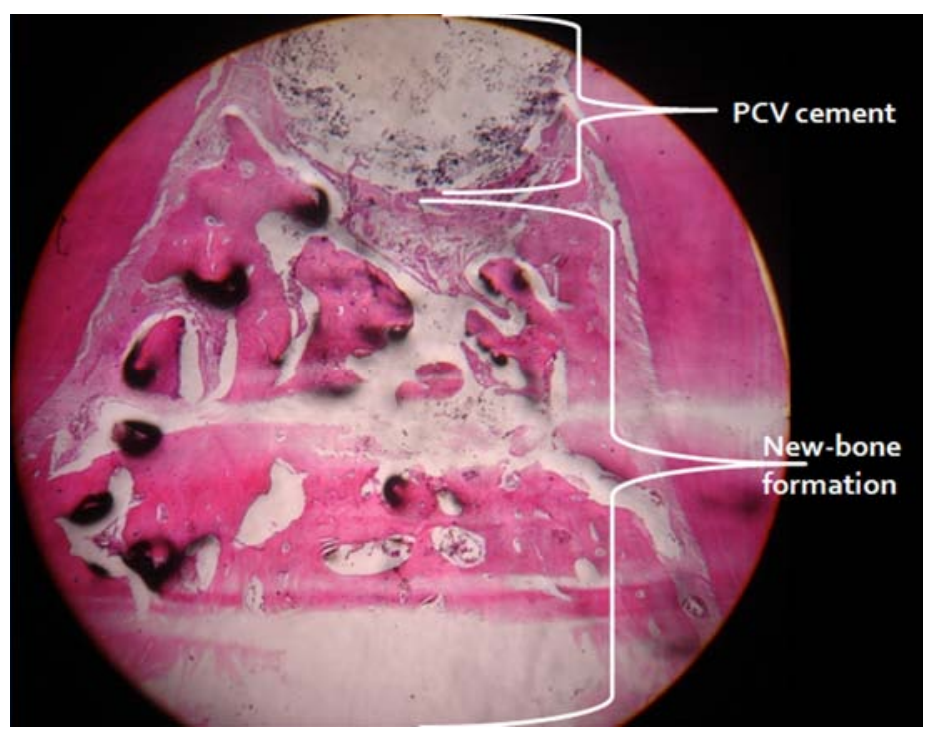

FIGURE 1 - Furcation treated with type V Portland cement. New-bone formation 


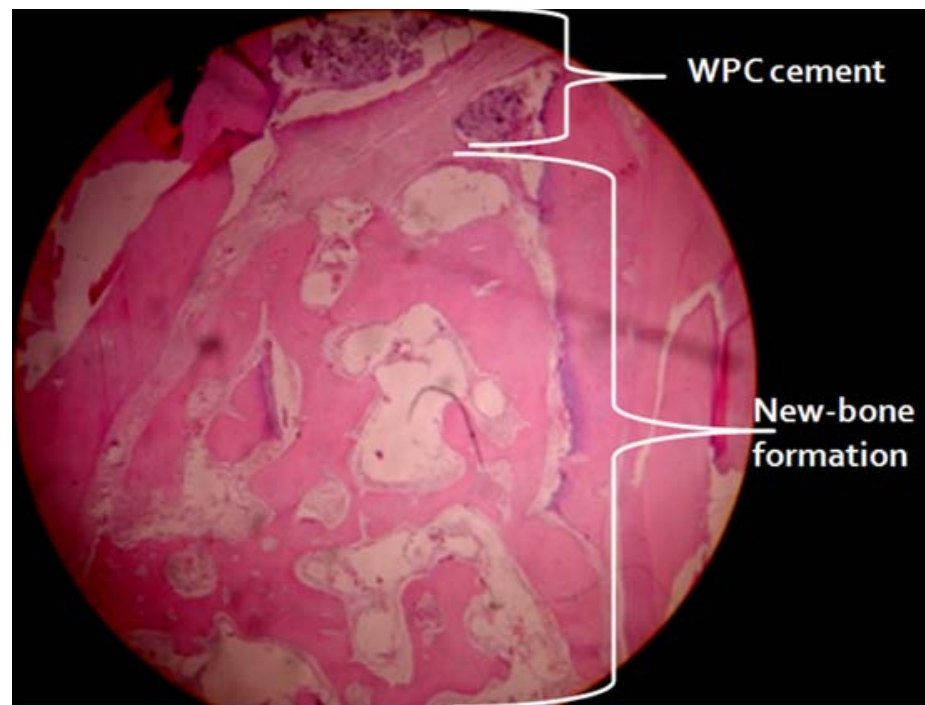

FIGURE 2 - Furcation treated with white Portland cement. New-bone formation

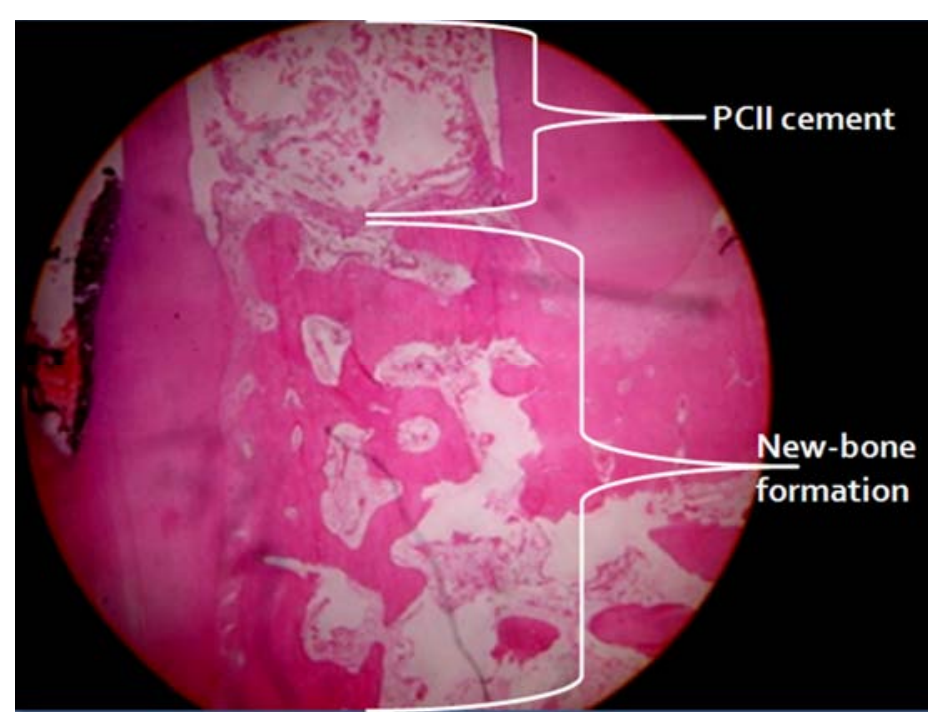

FIGURE 3 - Furcation treated with type II Portland cement. New-bone formation

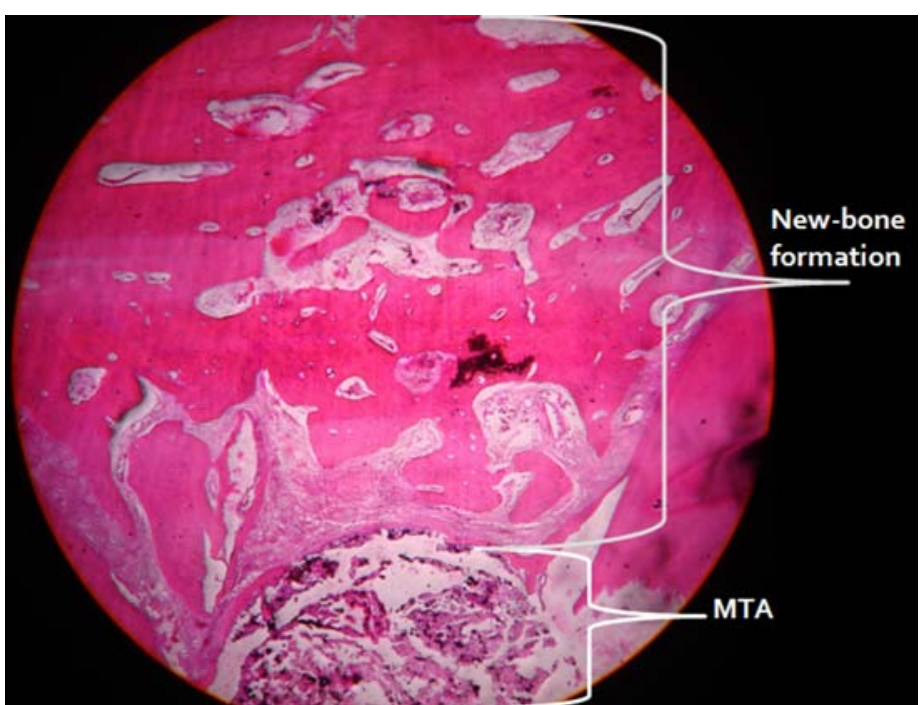

FIGURE 4 - Furcation treated with MTA. New-bone formation

\section{Discussion}

Root perforations adversely affect the prognosis of the endodontic treatment, occurring most frequently on the floor of the pulp chamber ${ }^{3}$. MTA is a biomaterial that can induce biomineralization and has been used to seal root perfortations ${ }^{20}$. Prognosis of root perforations has improved since MTA was introduced. However, its high cost limits its use. Studies on MTA have demonstrated that its composition is the same as the Portland cement used in construction and that the physical and biological properties of these cements are similar ${ }^{9,11}$. Further studies are necessary to better determine the biological properties of Portland cements. Because of the low cost, Portland cements could be used in the public health sector in cases where MTA is indicated.

The composition of MTA is the same as that of type I Portland cement without additives. MTA has low resistance to compression $^{12}$, which is a disadvantage for its use as a sealant in root perforations. Bismuth oxide has been added to MTA to make the aggregate radiopaque. A recent study revealed that bismuth oxide added to ordinary Portland cement alters the physical properties of the cement, lowering its mechanical resistance and increasing its porosity ${ }^{17}$. The study also demonstrated that besides lowering the resistance to compression, the addition of bismuth oxide adversely affects the physical properties of MTA, contraindicating its use as a sealant in root perforations, especially in cases where high-resistance materials are recommend, such as furcation perforations. Studies comparing the biological properties of MTA and Portland cements have used Portland cements without additives $^{13,16}$. Additives may improve the mechanical resistance of the cement, but also damage periradicular tissues.

In the present study, the biological properties of three types of Portland cements containing additives and their possible use in furcation perforations were evaluated. The basic requirements for cements used to obturate root perforations are to provide hermetic sealing, be biocompatible, and function as a precursor in the formation of carbonated apatite, inducing biomineralization. This process results in the formation of a layer of periodontal ligament on the bone, cementum-dentin interface ${ }^{20}$.

In this study, great importance was given to this interface during the development of the methodology. The furcation perforation was divided into dentin and bone perforations. The cement must remain in the dentinal portion of the canal, so as to cause no further damage ${ }^{4}$. The calcium sulfate barrier has been shown to maintain space for bone regeneration in the calvaria of Wistar rats, allowing the migration of osteogenic cells ${ }^{4}$. The calcium sulfate implant is used in furcation perforations especially because it is an osteoconductor, a hemostatic agent, and a biodegradable and biocompatible barrier for guided tissue regeneration (GTR) that prevents epithelial downgrowth and connective tissue ingrowth inside the canal, and stimulates bone growth ${ }^{5}$.

A study of MTA ProRoot, MTA Angelus and white Portland cement use in furcation perforations of premolars of dogs without the placement of barriers in the bone portion of the canal showed that this type of treatment resulted in the formation of intensive inflammatory infiltrates ${ }^{15}$. The authors did not recommend 
the use of white Portland cement in endodontics because it can cause an adverse reaction when placed in contact with periodontal tissues $^{15}$. The evaluation of the methodology used by these authors suggests that the determining factor triggering the inflammatory reaction was the contact of white Portland cement, as well as other obturation materials, with the periodontal tissue due to the lack of a biological barrier in the bone portion of the canal. In the present study, calcium sulfate was placed in the bone portion of the canal prior to the obturation of the dentinal portion with cement, which is in agreement with other studies ${ }^{4,5,15,20}$. This assures that this portion of the canal contains a biological matrix, so that the cements can provide an adequate seal of the root canal surface, with good adhesion to the dentin surface.

The anatomical arrangement of premolar teeth in dogs is favorable for the study of furcation perforations ${ }^{19}$. Immediate repair of the perforations offers the best results for perforation repair. Better results have been obtained in perforations performed on the proximal or palatal side than on the buccal side of the tooth ${ }^{1}$.

The early diagnosis and treatment favorably affects the outcome, minimizing damage to periodontal tissues. The floor of the pulp chamber is subject to the largest number of perforations of the "direct" type, which are defects caused by "hollowing out" the chamber with the bur towards the furcation; the perforation in this case is accessible, small and with walls ${ }^{1}$.

In the present study, the dimensions of the perforations were determined using a $1016 \mathrm{HL}$ bur in a water-cooled high speed handpiece oriented along the long axis of the tooth ${ }^{1}$. A direct perforation with walls was performed by hollowing out the pulp chamber, and slightly directed to the lingual or palatal side. The obturations were carried out immediately after perforations ${ }^{15}$.

This study was carried out to calibrate instruments and methods for a future study using a larger sample. The procedure time was reduced by isolating a dental quadrant with 6 teeth, allowing the test teeth to be treated simultaneously. Backhaus towel clamps, Gosset retractor, rubber dam, and clamps 206 were used in the surgical procedure. A coronal opening was made lateral to the cusps, which were preserved. The depth of the perforation was measured from the cursor of the 1016 HL bur, using the cusp tip as a reference point. A photopolymerized composite resin was used for the restoration of the teeth. For the preparation of the histological slides, the teeth were cut along the proxy-proximal direction, separating the lingual and buccal surfaces.

The small sample (teeth from only one dog) limited the results of the descriptive statistical analysis. However, this study served as preparation for a future study in which new-bone formation and inflammatory infiltrate will be evaluated in histological sections using digital planimetry and an image tool software.

Despite the presence of inflammatory infiltrate in the histological sections, new-bone formation was more pronounced.

\section{Conclusion}

All cements used in this study induced new-bone formation.

\section{References}

1. Al-Daafas A, Al-Nazhan S. Histological evaluation of contaminated furcal perforation in dogs' teeth repaired by MTA with or without internal matrix. Oral Surg Oral Med Oral Pathol Oral Radiol Endod. 2007;103:92-9. 2. Tsesis I, Fuss Z. Diagnosis and treatment of accidental root perforations. Endod Top. 2006;13:95-107.

3. Silva MJ, Caliari MV, Sobrinho AP, Vieira LQ, Arantes RM. Um modelo experimental in vivo para avaliar lesões de furca como resultado da perfuração. Int Endod J. 2009;42:922-9.

4. Silveira LR, Machado AR, Silveira RC, Oliveira BR. Bone repair process in calvarial defects using bioactive glass and calcium sulfate barrier. Acta Cir Bras. 2008;23:4-7.

5. Sellera DP, Mora AO, Ferreira CA. Utilização clínica do sulfato de cálcio na endodontia: técnica e aplicação. Rev Assoc Paul Cir Dent. 2005;59:137-43.

6. Bernabé PFE, Cintra LTA, Bernabé DG, Almeida JFA. Healing process of root end treatment using ultrasonic instrument and MTA or Portland cement. Int Endod J. 2002;55:65-9.

7. Tenório JAS, Silva FG, Pereira SS, Ferreira AV, Espinosa DCR, Barros A. Decomposição da fase majoritária do cimento Portland - Parte II: alita com adições de Fe e Al. Rev Esc Minas. 2003;56:2-5.

8. Funteas UR, Wallace JA, Fochtman EW. A comparative analysis of mineral trioxide aggregate and Portland cement. J Endod. 2003;29:43-4. 9. Duarte MA, Demarchi AC, Yamashita JC, Kuga MC, Fraga SC. pH and calcium ion release of 2 root-end filling materials. Oral Surg Oral Med Oral Pathol Oral Radiol Endod. 2003;95:345-7.

10. Tolentino E, Lameirasa FS, Gomesb AM, Gomesb R, Vasconcelosc WL. Effects of high temperature on the residual performance of Portland cement concretes. Mat Res. 2002;5:3-6.

11. Abdulah D, Pitt Ford TR, Papaioannou S, Nicholson J, McDonald F. An evaluation of accelerated Portland cement as a restorative material. J Endod. 2002;23:4001-10.

12. Húngaro Duarte MA, Oliveira El Kadre GD, Vivan RR, Guerreiro Tanomaru JM, Tanomaru Filho M, Moraes IG. Radiopacity of portland cement associated with different radiopacifying agents. J Endod. 2009;35:737-40.

13. Menezes R, Bramante CM, Letra A, Carvalho VG, Garcia RB. Histologic evaluation of pulpotomies in dog using two types of mineral trioxide aggregate and regular and white Portland cements as wound dressings. Oral Surg Oral Med Oral Pathol Oral Radiol Endod. 2004;98:376-9.

14. Trindade AC, Oliveira EP, Figueiredo JA. Comparative analysis of the tissue response to mineral trioxide aggregate (MTA), Portland cement and Portland cement to radiopaque substance. J Bras Endod. 2003;4:309-14. 15. Broon JN, Bramante CM, Assis GF, Bortoluzzi EA, Bernardineli N, Moraes IG, Garcia RB. Healing of root perforations treated with mineral trioxide aggregate (MTA) and Portland cement. J Appl Oral Sci. 2006;14:305-11.

16. Min KS, Kim HI, Park HJ, Pi SH, Hong CU, Kim EC. Human pulp cells response to Portland cement in vitro. J Endod. 2007;33:163-6.

17. Bueno CE, Zeferino EG, Manhães LR, Rocha DG, Cunha RS, Martin AS. Study of the bismuth oxide concentration required to provide Portland cement with adequate radiopacity for endodontic use. Oral Surg Oral Med Oral Pathol Oral Radiol Endod. 2009;107:65-9.

18. Moore J, Fitz-Walter P, Parashos P. A micro-computed tomographic evaluation of apical root canal preparation using three instrumentation techniques. Int Endod J. 2009;42:1057-64.

19. Lacerda MS, Simone TO, Daise NQ. Anatomical variations in the dentition of mongrel domestic dogs. Cienc Rural. 2000;30:4.

20. Reyes-Carmona JF, Felippe MS, Felippe WT. Biomineralization ability and interaction of mineral trioxide aggregate and white Portland cement with dentin in a phosphate-containing fluid. J Endod. 2009;35:731-6. 
Conflict of interest: none Financial source: none

\section{Correspondence:}

Lydia Masako Ferreira

Universidade Federal de São Paulo

Disciplina de Cirurgia Plástica

Rua Napoleão de Barros, 715/ $4^{\circ}$ andar

04024-900 São Paulo - SP Brasil

Phone: (55 11)5576-4118

lydia.dcir@epm.br

Received: March 23, 2010

Review: May 18, 2010

Accepted: June 16, 2010

\section{How to cite this article}

Silva Neto JD, Brito RH, Schnaider TB, Gragnani A, Engelman M, Ferreira LM. Root perforations treatment using mineral trioxide aggregate and Portland cements. Acta Cir Bras. [serial on the Internet] 2010 Nov-Dec;25(6). Available from URL: http://www.scielo.br/acb

*Color figures available from www.scielo.br/acb 